\title{
New records of the Endangered Chacoan peccary Catagonus wagneri suggest a broader distribution than formerly known
}

\author{
Ricardo Torres, Daniela Tamburini, Julián Lescano and Enzo Rossi
}

\begin{abstract}
The Chacoan peccary Catagonus wagneri is the rarest and most threatened of the three extant species of peccary. Its presence has been recorded in the northern Dry Chaco ecoregion, which spans northern Argentina, western Paraguay and south-eastern Bolivia. However, distribution models based on its occurrence in Argentina have predicted that suitable habitat extends southwards into central Argentina, where the species was not previously recorded. We present several records of the species outside the currently accepted distribution, including the first two records in the west of Córdoba province, $>650 \mathrm{~km}$ south of the southern limit of the previously known distribution. The discovery of the Chacoan peccary in central Argentina could serve as a justification for the protection of Chacoan forests in this region, where deforestation rates are among the highest worldwide.
\end{abstract}

Keywords Argentina, Catagonus wagneri, Chaco, Chacoan peccary, Córdoba, Tayassuidae

To view supplementary material for this article, please visit http://dx.doi.org/10.1017/So030605315001404

mong the three extant species of peccary the
Endangered Chacoan peccary Catagonus wagneri
(Altrichter et al., 2014) is the rarest and the most threatened.
The species was first described by Rusconi (1930), as a sub-
fossil, and was rediscovered as an extant species in Paraguay
by Wetzel et al. (1975). Later, the presence of the Chacoan
peccary was confirmed in the Paraguayan departments of
Boquerón, Alto Paraguay and west of Presidente Hayes, in
western Formosa, northern Chaco, eastern Salta and the

Ricardo Torres (Corresponding author) Museo de Zoología, Facultad de Ciencias Exactas, Físicas y Naturales, Universidad Nacional de Córdoba, Av. Vélez Sarsfield 299 (5000) Córdoba, Argentina. E-mail rtorres44@gmail.com

Daniela Tamburini and Enzo Rossi Instituto de Investigaciones Biológicas y Tecnológicas (Consejo Nacional de Investigaciones Científicas y Técnicas) and Centro de Ecología y Recursos Naturales Renovables, Facultad de Ciencias Exactas, Físicas y Naturales, Universidad Nacional de Córdoba, Córdoba, Argentina

JULIÁN LeSCANo Instituto de Diversidad y Ecología Animal (Consejo Nacional de Investigaciones Científicas y Técnicas) and Centro de Zoología Aplicada, Facultad de Ciencias Exactas, Físicas y Naturales, Universidad Nacional de Córdoba, Córdoba, Argentina

Received 8 September 2015. Revision requested 29 October 2015.

Accepted 7 December 2015. First published online 28 March 2016. far north of Santiago del Estero provinces in Argentina, and east of Tarija and south of Santa Cruz (and probably east of Chuquisaca) provinces in Bolivia (Mayer \& Wetzel, 1986; Taber, 1993; Chébez, 2008; Maffei et al., 2008; Fig. 1). Thus the known distribution of the species is restricted to the north and centre of the driest portion of the Chaco ecoregion. However, distribution models fitted only with occurrence localities from Argentina (Torres \& Jayat, 2010) showed that suitable habitats extended further south to the province of Córdoba in central Argentina. Here we present the first two records of the Chacoan peccary in the province of Córdoba and report several records $100 \mathrm{~km}$ or more beyond the limits of the currently accepted distribution (represented by the IUCN polygon, i.e. the polygon depicting the distributional area according to the criteria of IUCN experts; Altrichter et al., 2014).

The first record from Córdoba is a skull of an adult of unknown sex hunted in 2013 in the west of the province, c. $10 \mathrm{~km}$ west of El Cadillo, which we collected on 29 March 2015 and later deposited in the Mammal Collection of the Museo de Zoología of the Universidad Nacional de Córdoba (Supplementary Material 1). The skull was incomplete, lacking the lower jaw, but most of the cranial diagnostic characters (Mayer \& Wetzel, 1986) were evident: rostrum and nasal chambers more pronounced, a proportionately smaller braincase, a deeper zygomatic bar below the orbit, and a more posterior position of the orbit (with its anterior edge located well posterior to the last molar) than in the other peccary species; the infraorbital foramen well anterior to the zygomatic arch; and the lack of a pronounced articular fossa on the anterior face of the zygomatic arch (Plate 1). On 19 July 2015 we photographed a skull of an individual that had been hunted in Estancia Pinas in 2003 , c. $20 \mathrm{~km}$ from the locality of the first record (Plate 2). Both records were c. $650 \mathrm{~km}$ south-west of the IUCN polygon. The individuals were hunted in secondary forests typical of the southernmost Dry Chaco ecoregion (sensu Olson et al., 2001), with Aspidosperma quebracho-blanco as the emergent tree, Prosopis flexuosa, Cercidium praecox and Ziziphus mistol dominant in the tree stratum, Celtis ehrenbergiana, Larrea divaricata, Mymozyganthus carinatus, Acacia furcatispina, Acacia praecox, Opuntia sulphurea and Opuntia quimilo as the main components of the shrub stratum, and Deinacanthon urbanianum as the most abundant grass in the herbaceous stratum (Cabido et al., 1994). 


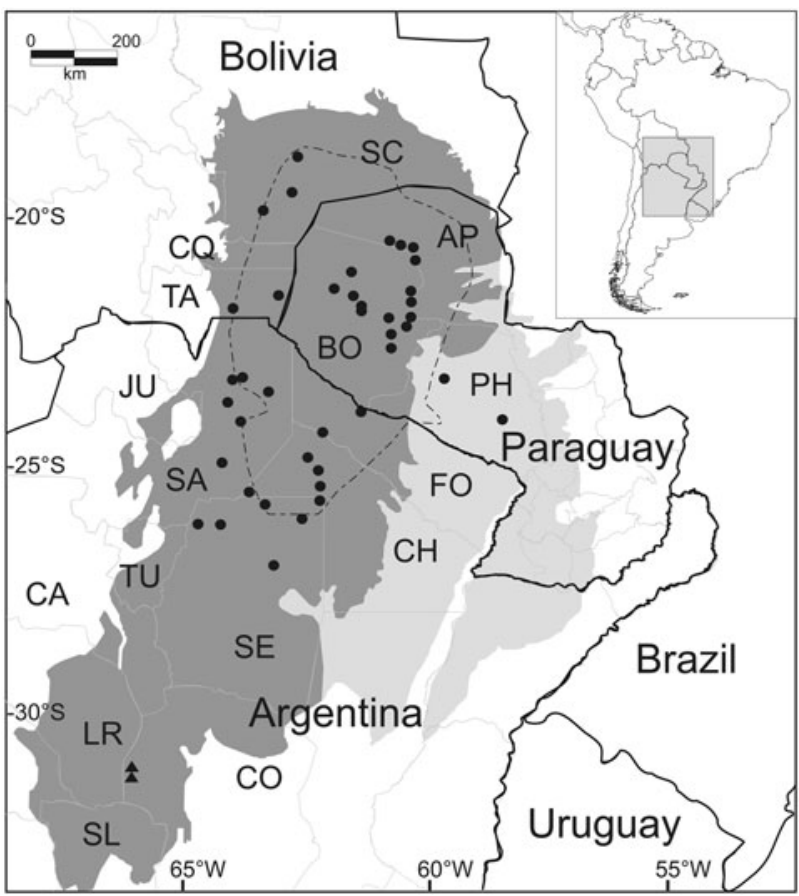

FIG. 1 Distribution of occurrence localities of the Chacoan peccary Catagonus wagneri from museum collections and the literature (circles), and the two new records reported here (triangles). The Dry Chaco ecoregion is shaded in dark grey and the Humid Chaco in light grey. The IUCN polygon (Altrichter et al., 2014) is delimited by a dashed line, representing the currently accepted range. Sub-national political boundaries are indicated only in those countries where the Chacoan peccary is present. SC, Santa Cruz; CQ, Chuquisaca; TA, Tarija; AP, Alto Paraguay; BO, Boquerón; PH, Presidente Hayes; JU, Jujuy; SA, Salta; FO, Formosa; CH, Chaco; SE, Santiago del Estero; TU, Tucumán; CA, Catamarca; LR, La Rioja; CO, Córdoba; SL, San Luis.

These findings were part of the results of 18 semistructured interviews (Guber, 2011; Valles, 2014) that we conducted during March-August 2015 in seven rural communities in an area of $751 \mathrm{~km}^{2}$ in the west and north-west of Córdoba province to gather information about the Chacoan peccary. Questions focused on the respondents' ability to distinguish the species, knowledge about its habits, and frequency of sightings. Seventy-two percent of the respondents mentioned this peccary species (known locally as chancho moro) as part of the local fauna. They were able to distinguish this species from the collared peccary Pecari tajacu, the only peccary species previously recorded in Córdoba (Morando \& Polop, 1997). They described it as a long-haired species, and bigger, faster and less gregarious (solitary or in pairs) than the collared peccary; all these characteristics are in agreement with the description of the Chacoan peccary. The fact that another species recorded recently in the same area, the lesser anteater Tamandua tetradactyla (Torres et al., 2009), was recognized by only two respondents and
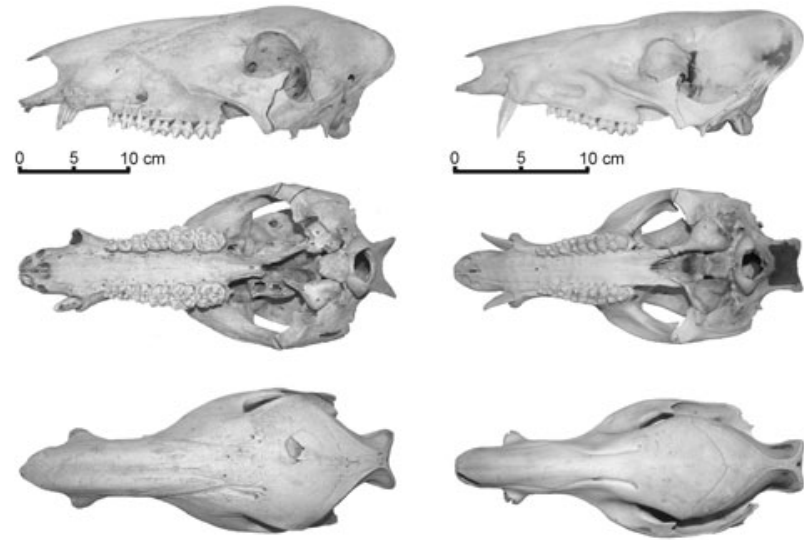

Plate 1 Lateral, ventral and dorsal views of the skulls of a Chacoan peccary Catagonus wagneri (MZUC-Ioo429) hunted 10 $\mathrm{km}$ west of El Cadillo, in the province of Córdoba in central Argentina (left) and of a collared peccary Pecari tajacu (MZUC-Ioo435) from La Paquita, in the province of Córdoba (right).

does not have a local name despite its striking appearance suggests the Chacoan peccary is not necessarily a recent immigrant.

We searched for records of the Chacoan peccary in museum collections and in the literature (Supplementary Material 1), and used maps, gazetteers and Google Earth (Google Inc., Mountain View, USA) to determine their geographical location. Museum databases often include the geographical coordinates of records, but locations are often approximate. We revised and improved these data for almost all records. We found a total of 53 presence localities for the species, attributable to a given location with an error $<5$ arc-minutes. Two localities were within the Humid Chaco (Fig. 1), 14 (26\%) were outside the IUCN polygon, and six $(11 \%)$ were $>100 \mathrm{~km}$ from the polygon limits, including our new records in Córdoba (Fig. 1).

Our findings highlight the need for further field research and biodiversity inventories in central Argentina, particularly in areas with Chaco forests. This is also an example of the value of local knowledge to researchers. Local people have long known of the presence of the Chacoan peccary in central Argentina, and its presence should not be surprising given that the environment in western and northern Córdoba is similar to that described for the species. In another example, the Chacoan naked-tailed armadillo Cabassous chacoensis was recorded in central-western Argentina, far from the nearest known presence locality in the north of the country (Tamburini \& Briguera, 2013 and references therein), although the species and its biology are well known by local inhabitants, who have historically used it as food.

Although there is no information about the existence of the Chacoan peccary in the area between Córdoba and the 


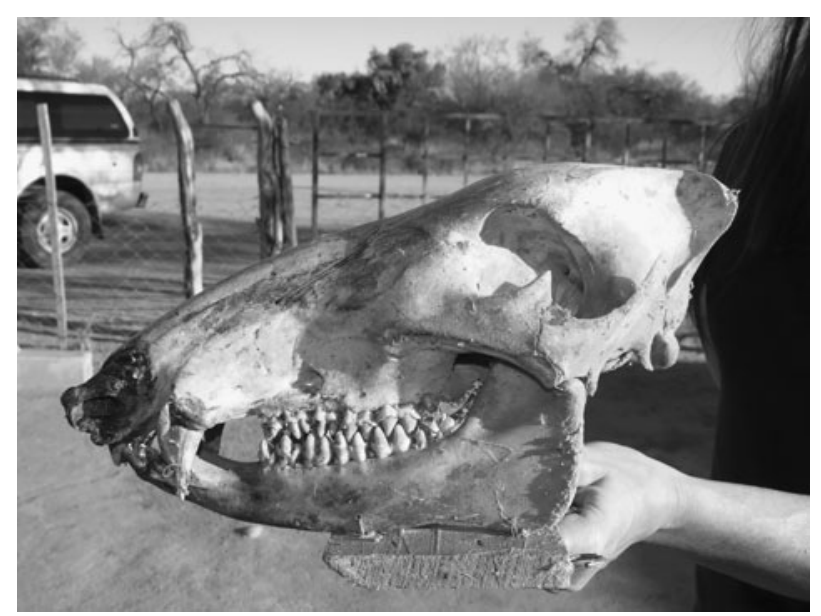

PLATE 2 Skull of a Chacoan peccary hunted by local people in Pinas, west of Córdoba province, Argentina, in 2003.

region covered by the IUCN polygon, it is possible that the population in Córdoba is not isolated. There is continuous forest linking both areas, as shown by the most recent land cover classifications (Morales Poclava et al., 2007; Clark et al., 2010), with climatically suitable conditions (Torres \& Jayat, 2010).

Even if the presence of the Chacoan peccary is confirmed in those areas linking Córdoba with the rest of its known distribution, we believe that the current international and national conservation status should not be changed. The Chaco ecoregion is threatened by land-use change (Grau et al., 2005; Aide et al., 2012), and deforestation rates in Córdoba province are among the highest in Latin America and worldwide (Zak et al., 2008). Furthermore, the Chacoan peccary is heavily hunted by local people in Córdoba, as in the rest of its distribution (Altrichter et al., 2014). However, we believe there is still an opportunity to conserve this population, considering the connectivity with similar habitats further north. Accordingly, we consider that the presence of this Endangered species could be used as an important justification for protection of the remnant forests in Central Argentina.

\section{Acknowledgements}

We are indebted to Eulogio Quiroga, Abraham Quiroga, Nicolás Flores and Nicolás Rodrigues for their help with field work. We also thank the following curators: Sergio Bogan (Fundación de Historia Natural Félix de Azara), Janet Brown (Oklahoma Museum of Natural History), Mónica Díaz (Fundación Miguel Lillo), David Flores (Museo Argentino de Ciencias Naturales Bernardino Rivadavia), and Itatí Olivares and Diego Verzi (Museo de Ciencias Naturales de La Plata). Some occurrence records were obtained from the Global Biodiversity Information Facility database. This work was partially funded by Fondo
Nacional de Ciencia y Técnica, Argentina (FONCyT, PICT No. 1693-2006) and Secretaría de Ciencia y Tecnología, Universidad Nacional de Córdoba, Argentina (Grant N ${ }^{\circ}$ 1565-2014).

\section{References}

Aide, T.M., Clark, M.L., Grau, H.R., López-Carr, D., Levy, M.A., Redo, D. et al. (2012) Deforestation and reforestation of Latin America and the Caribbean (2001-2010). Biotropica, 45, 262-271.

Altrichter, M., Taber, A., Noss, A., Maffei, L. \& Campos, J. (2014) Catagonus wagneri. In The IUCN Red List of Threatened Species v. 2015-4. Http://www.iucnredlist.org/ [accessed 2 April 2015].

Cabido, M., Manzur, A., Carranza, L. \& González Albarracín, C. (1994) La vegetación y el medio físico del Chaco Árido en la provincia del Córdoba, Argentina Central. Phytocoenologia, 24, 423-460.

Chébez, J.C. (2008) Los que se van. Fauna argentina amenazada. Tomo 3. Albatros, Buenos Aires, Argentina.

Clark, M.L., Aide, T.M., Grau, H.R. \& Riner, G. (2010) A scalable approach to mapping annual land cover at $250 \mathrm{~m}$ using MODIS time series data: a case study in the Dry Chaco ecoregion of South America. Remote Sensing of Environment, 114, 2816-2832.

Grau, H.R., Gasparri, N.I. \& Aide, T.M. (2005) Agriculture expansion and deforestation in seasonally dry forests of north-west Argentina. Environmental Conservation, 32, 140-148.

Guber, R. (2011) La etnografía. Método, campo y reflexividad. Siglo XXI, Buenos Aires, Argentina.

Maffei, L., Cuéllar, R.L. \& Banegas, J. (2008) Distribución del solitario (Catagonus wagneri) en Bolivia. Ecología en Bolivia, 43, $141-145$.

Mayer, J.J. \& Wetzel, R.M. (1986) Catagonus wagneri. Mammalian Species, 259, 1-5.

Morales Poclava, P., Lizarraga, L., Elena, H., Noé, Y., Mosciaro, J., Vale, L. et al. (2007) Cobertura de suelo en el noroeste argentino (NOA) mediante land cover classification system (LCCS-FAO). Año 2007. INTA, EEA Salta, Argentina.

Morando, M. \& Polop, J.J. (1997) Annotated checklist of mammal species of Córdoba province, Argentina. Mastozoología Neotropical, 4, 129-136.

Olson, D.M., Dinerstein, E., Wikramanayake, E.D., Burgess, N.D., Powell, G.V.N., Underwood, E.C. et al. (2001) Terrestrial ecoregions of the world: a new map of life on Earth. A new global map of terrestrial ecoregions provides an innovative tool for conserving biodiversity. BioScience, 51, 933-938.

Rusconi, C. (1930) Las especies fósiles argentinas de pecaríes (Tayassuidae) y sus relaciones con las de Brasil y Norteamérica. Anales del Museo Nacional de Historia Natural Bernardino Rivadavia, 36, 121-241.

Taber, A. (1993) The Chacoan peccary (Catagonus wagneri). In Pigs, Peccaries and Hippos: Status Survey and Conservation Action Plan (ed. W.R.L. Olivier), pp. 22-28. IUCN, Gland, Switzerland.

Tamburini, D. \& Briguera, V. (2013) Nuevo registro del cabasú chaqueño, Cabassous chacoensis Wetzel, 1980 para la Provincia de Córdoba, Argentina. Edentata, 13, 69-71.

Torres, R. \& JAYAT, J.P. (2010) Modelos predictivos de distribución para cuatro especies de mamíferos (Cingulata, Artiodactyla y Rodentia) típicas del Chaco en Argentina. Mastozoología Neotropical, 17, 335-352. 
Torres, R., Monguillot, J., Bruno, G., Michelutti, P. \& Ponce, A. (2009) Ampliación del límite austral del oso melero (Tamandua tetradactyla) en la Argentina. Nótulas Faunísticas, Segunda Serie, 39, $1-5$.

Valles, M.S. (2014) Entrevistas Cualitativas. Cuadernos Metodológicos $\mathrm{N}^{\circ} 32$, 2nd edition. Centro de Investigaciones Sociológicas, Madrid, Spain.

Wetzel, R.M., Dubos, R.E., Martin, R.L. \& Myers, P. (1975) Catagonus, an "extinct" peccary, alive in Paraguay. Science, 189 , 379-381.

Zak, M., Cabido, M., Cáceres, D. \& Díaz, S. (2008) What drives accelerated land cover change in central Argentina? Synergistic consequences of climatic, socioeconomic, and technological factors. Environmental Management, 42, 181-189.

\section{Biographical sketches}

RICARDO TORRES's research focuses on the application of species distribution models to mammal conservation in South America. DANIELA TAMBURINI and Enzo Rossi are interested in the biology of mammals, particularly Xenarthrans, in Central Argentina. Julián LESCANO studies anthropogenic factors affecting wildlife in central Argentina. 